\title{
Structure and Bioactivity of Sulfated Polysaccharides
}

\author{
酸性多糖類の構造と生理活性
}

Toida, Toshihiko ${ }^{\text {; }}$ Chaidedgumjorn, Amornrut ${ }^{1}$; and Linhardt, Robert J. ${ }^{2}$

\author{
${ }^{1}$ Graduate School of Pharmaceutical Sciences, Chiba University 263-8522, JAPAN \\ ${ }^{2}$ Departments of Chemistry, Medicinal and Natural Products Chemistry, Chemical and Biochemical Engineering, \\ University of Iowa, Iowa City, Iowa, 52242, USA
}

FAX: +81-43-290-2895, +1-319-335-6634, E-mail: toida@p.chiba-u.ac.jp, robert-linhardt@uiowa.edu

Key Words: sulfated polysaccharides, chemical O-sulfonation, anti-coagulant activity, anti-HAase activity, molecular weight

\begin{abstract}
Sulfated polysaccharides including glycosaminoglycans show various chemical and biological functions. These functions strongly depend on the presence and spatial positioning of their sulfo groups. Therefore, chemical modifications such as partial, per- $O$-sulfonation or desulfonation are expected to alter the function of sulfated polysaccharides. There are many reports on the chemical modification of polysaccharides. This paper focuses on the investigation of both the chemical modification of polysaccharides and its effect biological function. A structure-activity relationship, SAR, is established on both intact and chemically modified polysaccharides.
\end{abstract}

要 約

グリコサミノグリカンを含む酸性多糖類は様々な化学的、 生物学的な機能を示す。これらの機能の多くは硫酸基の存在に 強く依存している。よってこれら多糖類の部分的硫酸化、完全 硫酸化あるいは脱硫酸化などの化学的修飾は、硫酸化多糖の示 す機能を制御できるものと期待されている。多糖類の化学的修 飾に関する論文は数多く、私たちもこれまで多糖類の化学修飾 のみならずその生物学的作用に関して検討してきた（構造-活性 相関、SAR)。本論文では天然および化学修飾した多糖類の構造 活性相関について最近の結果を示す。

\section{A. Introduction}

Sulfated polysaccharides occur in many plant and animal species and tissue types (1). There are two major classes of endogenous polyanionic compounds found in animal tissues, the PGs/GAGs and the mucins. These polyanions are found in pericellular locations, on the external surface of cell membranes, in the extracellular matrix occupying the spaces between cells and at the mucous membrane (2). The primary functions of the endogenous polyanions are believed to be roles in cell-cell communication, acting as a barrier between tissues, cell adhesion, reservoirs for growth factors and barriers to protect against pathogens (2). Plant tissues also contain acidic polysaccharides. While most of these are polycarboxylated, i.e., alginates and pectins, some algal species contain sulfated polysaccharides, i.e., fucoidans and carrageenans (3). These polysaccharides serve a number of structural and protective roles in plants. The extensive range of their physiological functions has only recently begun to be appreciated and explored.

Heparin is a highly sulfated, linear polysaccharide that is derived from animal tissues and is widely used as a clinical anticoagulant. Heparin is an acidic and polydisperse bioactive polysaccharide. It is comprised of a major (75-95\%) repeating

\section{A. 緒 言}

硫酸化多糖類は多くの植物、動物種、組織に見出される (1)。動物組織には主にプロテオグリカン・グリコサミノグリカ ン、ムチンの 2 つの内因性酸性多糖類が見出される。これらの 酸性多糖類は細胞周囲あるいは細胞表面に存在し、また細胞外 マトリックスとして細胞間を埋めている(2)。内因性酸性多糖類 の主な機能は細胞間の情報交換、組織間障壁、細胞接着、增殖 因子の貯蔵あるいは病原体に対する防御作用などが推定されて いる(2)。植物もまた主にアルギン酸やペクチンなどのポリウロ ン酸を含んでいるが、海草はフコイダンやカラゲナンなどの硫 酸化多糖を含むことが知られている(3)。これらの多糖類は植物 組織の構造維持や外部因子からの防御機構として働いているも のと考えられる。さらに様々な生理的な機能が推定されている がその研究は最近緒についたばかりである。

一方へパリンは高い硫酸過度をもつ動物由来の直鎖の酸性 多糖であり、血液抗凝固剤として広く用いられおり、さらに多 様な生物活性を示す生理活性多糖である。その主な $(75 ９ 5 \%)$ 二糖繰り返し単位は GlcNS6S $\alpha 1 \rightarrow 4 I d o A 2 S$ であり、これに微量 
disaccharide of $1 \rightarrow 4$ linked $N$-sulfo-6- $O$-sulfo-D-glucosamine and 2-O-sulfoiduronic acid with minor sequences containing variable levels of $O$ - and $N$ - sulfo groups and glucuronic acid. Heparan sulfate is structurally similar to heparin and is found in extracellular locations, thus, most of the endogenous biological functions ascribed to heparin probably result from heparan sulfate (4). Heparin has a variety of biological activities, and many of which are of interests because of their potential therapeutic utility. It is well established that the biological activities of heparin result from its binding to proteins, modulating their activities. These interactions are often very specific, e.g., the anticoagulant activity primarily results from its specific binding to antithrombin III (a serine protease inhibitor of thrombin and other coagulation proteases) at a discrete pentasaccharide sequence $(5,6)$.

As a result of the multiplicity of biological activities associated with heparin and its importance as a major pharmaceutical, substantial research effort has been dedicated to the discovery of heparin analogues. Heparinoids, defined as heparin analogues, are usually obtained from animal, plant and synthetic sources. Heparinoids mimic biological functions of heparin by interacting with heparin-binding proteins. The large number of heparin-binding proteins can be classified into small number of groups. The interaction of heparin-binding proteins with heparinoids usually involves both ionic and hydrogen bonding interaction.

\section{B. Sources of Sulfated Polysaccharides (7)}

Naturally occurring sulfated polysaccharides:

From animal sources: A major group of sulfated polysaccharides found in animal tissues are the glycosaminoglycans (GAGs). Dermatan sulfate (8) is found in a wide variety of tissues in virtually all animals, and has been used clinically as an antithrombotic agent. Chondroitin sulfates are considered to have low biological activity due to the absence of the flexible Liduronic acid, found in dermatan sulfate and heparin. Keratan sulfate (9), the only GAG not to possess an uronic acid residue, is an important component of cartilage and the cornea and involved in diseases associated with these tissues. Hyaluronan is a very high molecular weight unsulfated GAG. Chemical $O$-sulfonation of this polysaccharide affords a polysaccharide displaying several important biological activities such as anti-hyaluronidase activity (10).

From plant sources: Fucoidan, a homopolymer of sulfated L-fucose, has been isolated from plant tissue. Fucoidan is known to interfere the function of selectin (11), to inhibit LPSinduced leukocyte rolling (12) and adhesion on epithelial cell surface of aorta. Fucoidan also has been reported to have antithrombotic (13) and anti-infective activities. Carrageenans (14) are obtained by aqueous extraction of red seaweeds. They consist of sulfate esters of $(1 \rightarrow 3,4$ linked) D-galactose and 3,6-
ではあるが様々な $N$-、O-硫酸化度の異なるグルコサミンやグル クロン酸が見出される。ヘパラン硫酸は構造的にヘパリンに類 似してはいるが、ヘパリンと異なり多くの場合細胞外マトリッ クスに存在し、ヘパリンの示す生理活性の大部分はへパラン硫 酸が担っているものと考えられる(4)。へパリンが多くの生理活 性を示すことはよく知られており、その多くは医薬品としての 適応も含め、多くの関心を集めている。ヘパリンが活性を発現 するに当たって標的となるタンパク質と結合し、調節している ことはよく知られている。これらのへパリンータンパク質相互作 用は特異的で、特に抗凝固活性におけるアンチトロンビンIII（ト ロンビンやその他の凝固系セリンプロテアーゼインヒビター)に 対する特徵的五糖単位は特によく知られている $(5,6)$ 。

ヘパリンの示寸様々な生物活性や医薬品としての重要性か らこれまでへパリン様物質の発見に多くの精力が費やされた。 ヘパリン様物質、すなわちへパリノイドとしては動物、植物由 来あるいは合成によるものが知られているが、これらのへパリ ノイドはへパリン結合タンパク質に対して類似の挙動を示す。 多くのへパリン結合タンパク質はそれぞれ小さなグループに分 類されているが、ヘパリノイドのへパリン結合タンパク質に対 する結合もへパリンのそれと同じように静電気的であったり、 水素結合であったり様々である。

\section{B. 硫酸化多糖の由来 (7)} 天然由来硫酸化多糖

動物由来：主要な動物由来酸性多糖類はグリコサミノグリ カン $(\mathrm{GAGs})$ である。デルマタン硫酸 $(8)$ は実際すべての動物 の様々な組織に見出され、抗トロンビン薬として臨床で用いら れている。コンドロイチン硫酸はデルマタン硫酸、ヘパリンの 示す生理活性の本体と考えられている構造的自由度の高い L-イ ズロン酸を含まないため、生理活性物質としての認識は希薄で ある。GAG の中でも唯一ウロン酸を含まないケラタン硫酸 (9) は軟骨、角膜に見出され、これら組織の疾患に関与する場合が 多い。ヒアルロン酸は非常に高い分子量を有し、硫酸基を含ま ない。化学的に硫酸化したヒアルロン酸が抗ヒアルロニダーゼ 活性などのいくつか重要な生理活性示すことが報告されている (10)。

植物由来：唯一硫酸化 L-フコースからなる多糖フコイダン は植物から単離同定された。フコイダンはセレクチンの機能を 阻害し(11)、LPS 誘導白血球の血管壁ローリング、動脈内皮へ の接着を阻害する(12)。フコイダンはまた抗トロンビン作用 (13) や抗感染作用を有するといわれている。カラゲナン類は紅藻類 の抽出液から単離されている(14)。カラゲナンは部分的に硫酸 化された $(1 \rightarrow 3,4)$ D-ガラクトースと 3,6 アンヒドロ-D-ガラク 
anhydro-D-galactose copolymers. Carrageenans are widely used in food, pharmaceutical and industrial application (15).

Sulfonation of neutral polysaccharides: Chitin, poly (2acetamido-2-deoxy-D-glucopyranose), is the major organic component of the exoskeleton found in insects, crabs, etc. (16). Chitin can be de- $\mathrm{N}$-acetylated to prepare chitosan, which on chemical sulfonation has some structural similarity to heparin and inhibits thrombin activity through antithrombin $(17,18)$. Pentosan, a ( $1 \rightarrow 4$ linked) xylopyranose with a single branched 4-O-methyl- $\alpha$-D-glucuronic acid is extracted from the bark of the beech tree (19). On sulfonation, it has been shown to be an anticoagulant with one-tenth of heparin's activity. Dextran sulfate also is an inhibitor of human immunodeficiency virus (HIV) binding to T-lymphocytes but because of its low oral bioavailability it has not been used therapeutically (20). Laminarin, isolated from the cell wall of seaweed and composed of $(1 \rightarrow 3$ linked) glucose residues are chemically sulfonated which is effective in the prevention and treatment of ischemic cerebrovascular disease (21).

Fully synthetic sulfated polymers (22): Synthetic polymers such as poly(vinyl sulfate) and poly(anethole sulfonate) are highly charged heparin-like polyanions that exhibit anticoagulant activity (2). But the use of this agent in vivo has been precluded by their high toxicity. A small sulfonated molecule, suramin, was the first synthesized heparin analogue. It shows activity as an anthelmintic, an antiprotozoal, an antineoplastic and an antiviral agent $(23,24)$. Despite its potent activities, suramin has a long half-life and exhibits a wide range of toxic side effects.

\section{Biological Activities of Polysaccharides}

The only currently approved therapeutic applications of heparinoids are as anticoagulant/antithrombotic agents and for biomaterials used in medical devices (i.e., catheters, hollow fiber artificial kidneys, blood oxygenators). There are additional therapeutic areas that are under extensive investigation as described below.

Effect on smooth muscle proliferation: Heparin (25) and fucans (26) have demonstrated the ability to inhibit the proliferation of smooth muscle cells. The anticoagulant and antiproliferative effects of low molecular weight fucans on both coagulation and cell proliferation are dependent on their degree of sulfation (27).

Activation on immunosystem: The carbohydrate polymers $\beta-1,3-D-$ glucans on sulfonation exert potent effects on the immune system by binding to receptors on macrophages and other white blood cells and activating them (28).

Anti-inflammatory activity: Natural sulfated fucans have a potential for use as anti-complementary and anti-inflammatory agents (29), owing to its potent inhibitory effect on human complement activation.
トースからなる多糖である。カラゲナンは広く食料や医薬品と

してあるいは種々の工業原料として用いられている(15)。

中性糖の硫酸化：N-アセチルグルコサミンからなる多糖キチ ンは、昆虫、甲殼類の体表を覆う主要物質として知られている (16)。キチンは化学的に脱 $N$-アセチル化されキトゥサンとなり、 キトゥサンはさらに化学的に硫酸化されヘパリン様作用を示 し、アンチトロンビンを介して抗トロンビン作用を示すことが 知られている(17、18)。ペントサンは 1 個の 4-O-メチル D-グルク ロン酸枝分かれをもつ直鎖の $(1 \rightarrow 4)$ キシロースポリマーであ り、ブナ科の樹木より抽出されている(19)。化学的硫酸化された ペントサンはへパリンの十分の一の抗凝固活性を示す。デキス トラン硫酸もまた HIV の T-リンパ球への感染を阻害することが 知られているが、経口的な吸収に難があり、治療法としては確 立していない(20)。海草の細胞壁から単離されたラミナリンは (1 ３）グルコースから単離され、化学的に硫酸化され虚血性脳血 管症の予防・治療に効果を示す $(21)$ 。

合成硫酸化高分子(22)：ポリビニル硫酸やポリアネトールス ルホン酸などの合成高分子はへパリン様の抗凝固活性を示す (2) ことが知られているが、その高い生体に対する毒性のために実 際に使用されることはない。比較的小さな硫酸化された分子で あるスラミンは最初に合成されたへパリノイドであり、駆虫効 果や抗ウイルス作用が報告されている $(23 、 24)$ 。スラミンの潜在 的な薬理効果は期待できるが、体内寿命の長さや重篤な副作用 も懸念されている。

\section{C. 多糖類の生物活性}

唯一実用的に治療に応用されているへパリノイドは抗凝固 ・ 抗トロンビン試薬としてであり、カテーテル、人工腎臓、人工 肺などの医療用器具の内側にコーティング剤として実用化され ている。その他現在盛んに実用化が試みられている例を以下に 示す。

平滑筋増殖に対する影響：ヘパリン (25) およびフカン (26) は平滑筋細胞の増殖阻害作用を示すことが報告された。低分子 フカンの抗血液凝固、抗增殖活性はフカンの硫酸化度に依存す ることが明らかになった(27)。

免疫系の活性化： $\beta 1-3$ グルカンを硫酸化するとマクロ ファージや他の白血球受容体に結合することにより、あるいは 直接これらの細胞に作用し、免疫系を活性化することが知られ ている(28)。

抗炎症活性: 天然の硫酸化フカンは、ヒト補体活性化阻害作 用により抗補体および抗炎症試薬としての可能性を秘めている (29)。 
Antiangiogenic activity: Not only heparins but also carrageenans and semi-synthetic sulfated polysaccharides like laminarin sulfate were shown to be potent angiogenesis inhibitors $(30,31)$.

Anticancer activity: Heparin and other proteoglycans have a role in neoplasia in regulating the growth of endothelial cells and controlling the proliferation of other cells through its interaction with growth factors. Basic fibroblast growth factor (FGF) might be closely related to the malignant growth of prostate cancer in addition to tumor angiogenesis. Epidermal growth factors (EGF) and their receptors (EGFR) are also important in human cancer. This growth factor includes heparin-binding EGF, making the study of heparin or heparin analogs important in the design of new anticancer agents. Sulfated $\alpha-(1 \rightarrow 3)$-D-glucan (32), calcium spirulan (33), and other algae polysaccharides (34) exhibit inhibition of tumor invasion and metastasis properties.

Antiparasitic activity: Chondroitin sulfate A tetradecasaccharide (35) is the minimum length able to almost completely inhibit binding of malaria-infected erythrocytes to the microvascular endothelium of various organs. The adherence of infected erythrocytes (IEs) to the microvascular endothelium of various organs is a key feature of Plasmodium falciparum infection and contributes to the survival of parasites by aiding replication and evasion of splenic clearance.

Antiviral activity: Heparin and other sulfated polysaccharides particularly extracted from alga were found to be active against a wide variety of enveloped viruses such as HIV, herpes simplex virus type 1 and type 2 , influenza A virus, respiratory syncytial virus, simian immunodeficiency virus and human cytomegalovirus (36). Heparin and sulfated polysaccharides represent a wide variety of different biological activiti es. However, unwanted side effects of these pharmacologically active compounds have often been observed due to their multiple bioactivities. Substantial research effort has focused on the structural modifications of preparing heparin analogues that might exhibit higher specificity and decreased side effects in different therapeutic applications. These heparinoids can be prepared from animal, plant and microbial sources and through chemical synthesis.

To elucidate the structure-activity relationship (SAR) of sulfated polysaccharides, homopolysaccharides from natural sources were modified by sulfonation to alter their physiologi$\mathrm{cal} / \mathrm{pharmacological}$ properties. In the present study, $1 \rightarrow 3$, or $1 \rightarrow 4$ linked linear polysaccharides including xylan, amylose, cellulose, curdlan, which are commercially available, and sulfated D-galactan isolated from clams were used. Their biological activities, including anticoagulant (37) and hyaluronidase inhibition activities were then compared.

\section{Preparation of Per- $O$-Sulfo Polysaccharides}

Sulfated polysaccharides have many biological functions,
抗血管新生作用：ヘパリンだけでなくカラゲナンやラミナ リン硫酸などの半合成硫酸化多糖は血管新生阻害作用が知られ ている(30、31)。

抗がん作用：ヘパリンおよび他のプロテオグリカンは各種 増殖因子と結合することによって内皮細胞の増殖調節、他の細 胞増殖の制御など組織新形成に深く関与している。塩基性増殖 因子 (FGF) は前立腺がんの増殖に密接に関与しているのは間違 いない。表皮増殖因子 (EGF) およびその受容体 (EGFR) もまた ヒトがん細胞の増殖に重要である。EGFは新しい抗がん剂をデ ザインする上で、ヘパリンやへパリノイドの抗がん作用を調べ る格好の標的である。硫酸化 $\alpha 1 \rightarrow 3-\mathrm{D}-$ グルカン(32)、スピルラ ンカルシウム(33)、および他の藻類由来多糖(34)もまたがん浸 潤、転移の阻害活性を示す。

抗寄生虫作用：コンドロイチン硫酸 $\mathrm{A}$ 由来 14 糖 (コンドロ イチン 4 硫酸) がマラリア感染赤血球の多様な臓器の血管内皮 感染を完全に阻害する最小有効単位であることが報告された (35)。多様な臟器微小血管内皮細胞に対するマラリア感染赤血球 (IEs)の接着は、マラリア原虫の感染において鍵となる現象で、 複製、脾クリアランスからの回避などとともに生き残りに貢献 している。

抗ウイルス活性：ヘパリンや他の硫酸化多糖、特に藻類か ら単離された多糖は HIV、ヘルペスウイルス 1 および 2 型、イ ンフルエンザ A ウイルス、呼吸性合胞性ウイルス、SIV、ヒト 巨細胞ウイルスなどのエンベロープウイルスに対して有効であ ることが見出された(36)。ヘパリンや硫酸化多糖は幅広い多様な 活性を有しているが、これらを薬剤として用いようとするとこ れらが不要な副作用となることがしばしばある。そこでより特 異的な活性をもち、副作用のない治療薬を開発するために、へ パリン様物質を創製する化学的修飾に多くの努力が払われてき た。これらのへパリノイド類は動物界、植物界、あるいは微生 物などから広く探索され、更には化学合成を通じて創製しよう と試みられている。

硫酸化多糖類の構造活性相関 (SAR) を明らかにするため に、私たちは天然の単純多糖の本来有する生理的・薬理的活性 を部分的に変える目的で化学的に硫酸化を施した。今回、 $1 \rightarrow 3$ 結合あるいは $1 \rightarrow 4$ 結合をもつ数種の直鎖の多糖、寸なわち市販 のキシラン、アミロース、セルロース、カードラン、および二 枚貝から単離した硫酸化ガラクタンを例に行った。今回調製し たこれらの化学修飾した多糖の、抗凝固活性(37)、および抗ヒア ルロニダーゼ活性について比較検討した。

\section{D. 完全 $O$-硫酸化多糖類の調製}

硫酸化多糖は多くの生物活性を示すが、タンパク質に対す 
which depend on binding of highly specific carbohydrate structures to proteins. Heparin is the most highly charged polyanionic polymer found in nature. In 1950, it has been established that heparin in situ was covalently linked to core proteins through serine residues. In the 1940s, it was assumed that the anticoagulant activity of heparin was in part due to its high negative charge density. This hypothesis was supported by the finding that chemical sulfonation of neutral polysaccharides resulted in anticoagulant activity. These compounds containing various carbohydrate backbones and carboxyl- and sulfo groups are categorized as 'heparinoids'. They were chemically synthesized and their anticoagulant activity examined. To understand the chemical structure within these heparinoids that influence their biological activities, chemical modification reactions such as depolymerization, phosphorylation, sulfonation, regioselective sulfonation, and/or desulfonation was undertaken.

Recently, we prepared and characterized the structures of chemically fully sulfated $1 \rightarrow 3$, or $1 \rightarrow 4$ linked linear polysaccharides including xylan, amylose, cellulose, curdlan, which are commercially available, and sulfated D-galactan isolated from clams (Figure 1), and their biological activities were compared. Additionally, the contribution of 6- $O$-sulfo group for biological activity of chemically fully sulfated polysaccharides by using a specific $O$-desulfonation reaction was also investigated (37).

\section{E. Preparation and Characterization of Chemically Fully Sulfated Polysaccharides}

Various methods for sulfonation of hydroxyl groups of polysaccharides involving chlorosulfonic acid-pyridine complex, sulfuric acid mediated by dicyclohexylcarbodiimide (38), sulfur trioxide-trimethylamine complex (39), and pyridine-sulfur trioxide complex in $N, N$-dimethylformamide (DMF) as sulfonating reagent have been reported. In this study, the pyridine-sulfur trioxide complex in DMF, in which causes less depolymer-
る特異的結合による場合が多い。1950 年にヘパリンがセリン残 基を介してタンパク質に共有結合することが明らかになった が、1940 年代からへパリンの示す抗凝固活性はへパリンの有す る高い陰電荷密度によるものと考えられていた。この仮説は中 性多糖を硫酸化することによって抗凝固活性が出現することが 見出され、裏付けられた。多様な糖鎖骨格、カルボキシル基、 硫酸基をもつこれらの多糖を “ヘパリノイド”と称し、ヘパリ ンとは区別されている。ヘパリノイドは部分的に化学合成され たもので、凝固活性が調べられた。これらへパリノイドの生物 活性に影響する化学構造を理解するために、化学的低分子化、 リン酸化、硫酸化、位置選択的硫酸化あるいは脱硫酸化などが 行われている。

最近、私たちはキシラン、アミロース、セルロース、カー ドラン、および二枚貝から単離した硫酸化ガラクタン(図 1 )の 化学修飾を行い、その生理活性を調べた(37)。特に 6 位硫酸基 の意味を探るために完全硫酸化多糖から特異的な方法によって 6 位のみを選択的に脱硫酸化し、その影響を調べた。

\section{E. 化学的完全硫酸化多糖の調製と同定}

多糖の水酸基のスルホン化については数多くの方法が報告 されている。例えばクロロスルホン酸-ピリジン錯体、ジシクロ ヘキシルカルボジイミドと硫酸(38)、三酸化イオウートリメチル アミン錯体(39)、あるいは $N, N$-ジメチルホルムアミド (DMF) 中で三酸化イオウーピリジン錯体を用いる方法などが報告されて いる。ここでは反応中の糖鎖の分解・副反応が少ない三酸化イ
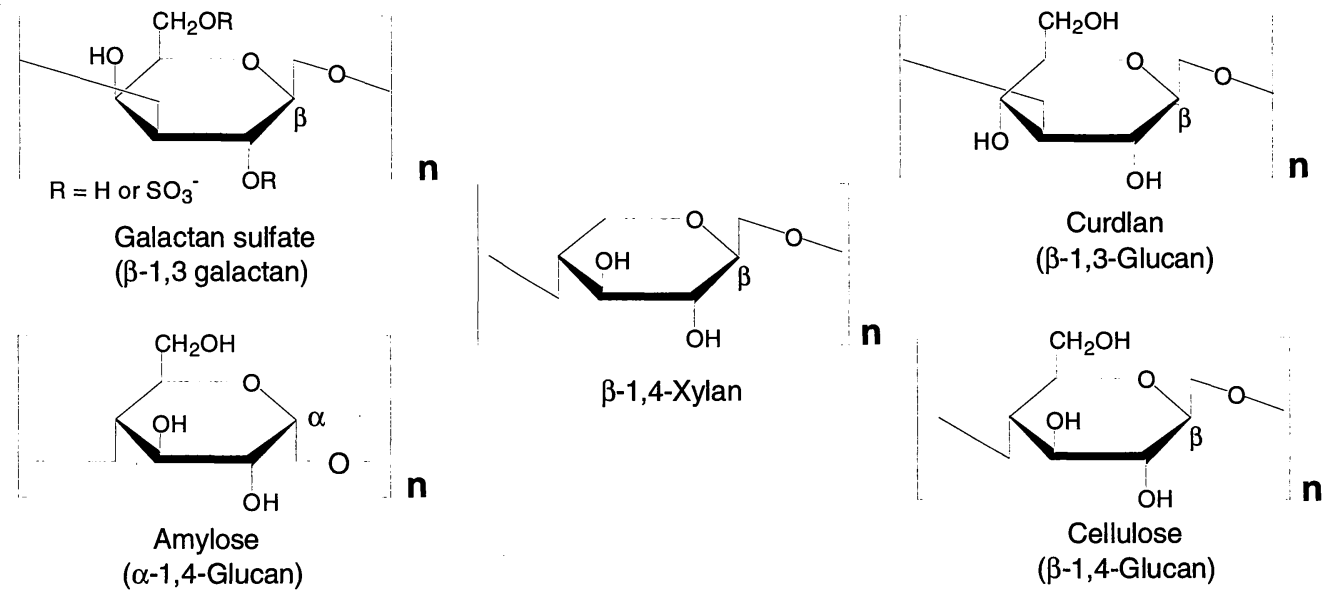

Fig. 1. Structure of polysaccharides discussed. 
Trends in Glycoscience and Glycotechnology Vol.15 No.81 (January 2003) pp.29-46

ization and side reactions was used to prepare fully sulfated polysaccharides (37).

\section{E-1. Preparation of Persulfonated Polysaccharides}

The $\beta 1 \rightarrow 3$ linked curdlan and D-galactan, $\beta 1 \rightarrow 4$ linked xylan ard cellulose, and $\alpha 1 \rightarrow 4$ amylose were subjected to full sulfonation to both increase their negative charge and decrease (or eliminate in the case of D-galactan isolated from clams) their sequence heterogeneity (Figure 1). In the previous reports (40, 41) chemical sulfonation was carried out under harsh conditions with adducts of sulfur trioxide in aprotic solvents to obtain fully sulfated polysaccharides. Each polysaccharide was allowed to swell well in dry DMF and was then stirred for $14 \mathrm{~h}$ at room temperature. An excess ( $15 \mathrm{~mol} /$ equivalent of available hydroxyl groups in polysaccharides) of sulfur trioxide-pyridine complex was required. The persulfonation reaction was carried out with stirring under $\mathrm{N}_{2}$ gas for $6 \mathrm{~h}$ at $40^{\circ} \mathrm{C}$. The resulting inorganic sulfuric acid was neutralized by an aqueous solution of $\mathrm{NaOH}$. The sulfated polysaccharide was precipitated with cold ethanol, re-dissolved in water, dialyzed against water, and lyophilized.

In the case of cellulose, because of the very highly molecular weight of this polysaccharide, a sample was partially depolymerized under mild acid hydrolysis and sulfonation was repeated to afford fully sulfated cellulose. Different conditions were also investigated to obtain other fully sulfated polysaccharides and to prepare oversulfated polysaccharides with different levels of sulfation. Various types of sulfonation reactions, relying on different mechanisms, were considered for polysaccharides with different types of glycosidic linkages such as $\beta 1 \rightarrow 3$ and $\beta 1 \rightarrow 4$, and ones with different constituent sugar residues.

\section{E-2. Preparation and Characterization of Chemically 6-O-} Desulfonated Polysaccharides

Sulfated polysaccharides are found in most algal cell matrices, and those of animal origins are also well known as mucopolysaccharides. The biological activities of these sulfated polysaccharides have been investigated for development of new medicinal materials, and many papers have reported a variety of sulfonation and desulfonation $(41,42)$. One of the most convenient methods of desulfonation involves treatment with dilute methanolic hydrogen chloride and was originally applied to desulfonation of chondroitin sulfate (43). Unfortunately, this method also causes considerable depolymerization and reduction in yield because of concomitant cleavage of glycosidic linkages. An improved yield of desulfonated polysaccharides can be obtained without serious decomposition by the solvolysis of the pyridinium salts of polysaccharides in an aprotic solvent, such as dimethylsulfoxide, $N, N$-dimethylformamide, and pyridine, or dimethylsulfoxide, containing a small amount of water or methanol $(44,45)$. The other advantage of solvolytic desulfonation is that selective $N$-desulfonation can be achieved by careful control of the reaction conditions (44). Additionally, a specific $O$-desulfonation method has been reported that in-
オウーピリジン錯体を DMF 中で用いる方法について紹介する (37)。

\section{E-1. 完全硫酸化多糖の調製}

$\beta 1 \rightarrow 3$ 結合を有するカードランとガラクタン、 $\beta 1 \rightarrow 4$ 結合を 有するキシラン、セルロースおよび $\alpha 1 \rightarrow 4$ 結合をもつアミロー スについて、陰電荷の増加および糖鎖配列の複雑さの減少 (ある いは二枚貝由来ガラクタンの場合ではランダムな位置での複雑 な硫酸化パターンの除去) を目的に化学的硫酸化反応に供した (図 1)。以前発表された論文 $(40 、 41)$ によれ゙、完全化学的硫酸 化は強い条件下で、非プロトン性の溶媒中で行われていた。今 回個々の多糖を DMF 中によく溶媒になじませるため、硫酸化 反応前に 14 時間室温で攪找した。次に硫酸化試薬である三酸化 イオウーピリジン錯体を過剩に加え (多糖中の水酸基のモル数に 対して 15 倍当量の硫酸化試薬)、窒素ガス置換後 $40^{\circ} \mathrm{C} 、 6$ 時間 反応にかけた。反応中に生成してくる硫酸基を水酸化ナトリウ ムで中和し、冷エタノールを加えて多糖を沈殿とし、水に再度 溶かして透析後凍結乾燥した。

セルロースの場合、分子量が非常に高いことが予想された のであらかじめ弱い酸で部分加水分解し完全硫酸化反応に供し た。反応条件は種々検討し、硫酸化度の異なる部分硫酸化体も 調製した。

\section{E-2. 化学的脱 6-O-硫酸化多糖類の調製}

硫酸化多糖はほとんどの藻類に見出され、また動物由来で はムコ多糖としてょく知られている。これら硫酸化多糖の生物 活性については新しい医薬品の開発を目的に研究されており、 硫酸化、脱硫酸化に関する論文は多数報告されている $(41 、 42)$ 。 もっとも簡便な脱硫酸化法の一つにメタノール性塩酸で処理す る方法があり、コンドロイチン硫酸からコンドロイチンへの脱 硫酸化にはじめて用いられた(43)。しかしこの方法は脱硫酸化反 応と同時にグリコシド結合の開裂が起こり、かなりの低分子 化、回収率の低下を生じる。そこで改良法として硫酸化多糖の ピリジン塩を、少量の水またはメタノールを含む非プロトン溶 媒中、例えば DMSO 単独、DMF-ピリジンあるいは-DMSO 混 合溶媒中でソルボリシスする方法が開発された $(44 、 45)$ 。ソルボ リシスによる脱硫酸化反応の利点は、反応条件を注意深く制御 することにより、選択的に $N$-硫酸基をはずすことができる点で ある(44)。加えて、位置選択的な脱 $O$-硫酸化反応が相次いで報 
volves the treatment of pyridinium salts of methyl $\alpha$-Dgalactopyranoside 2,6-disulfate (46) and polysaccharide sulfates $(47,48)$ with $N, O$-bis(trimethylsilyl)acetamide (BTSA), $N, O$ bis(trimethylsilyl)trifluoroacetamide (BSTFA), or $N$-methyl- $N$ (trimethylsilyl)trifluoro $\rightarrow$ acetamide (MTSTFA) in pyridine. This reaction supposedly does not involve a solvolytic process, as desulfonation does not occur when other silylating reagents, such as $N, O$-bis(trimethylsilyl)carbamate, $N$ trimethylsilylimidazole (TSIM), and iodotrimethylsilane, under similar conditions (46). BTSA in pyridine is useful for the selective desulfonation of fully sulfated neutral polysaccharides, affording 6-O-desulfonation without depolymerization of the polysaccharide chains. This method has been applied to elucidate the effect of 6-O-sulfo groups on the various biological activities of fully sulfated polysaccharides.

\section{E-3. Preparation of 6-O-Desulfonated Persulfonated Polysac- charides}

Fully sulfated amylose, cellulose, curdlan, and galactan were 6- $O$-desulfonated by using BTSA in pyridine. The procedure for the regioselective 6-O-desulfonation of fully sulfated polysaccharides is as follows. An aqueous solution of the sodium salt of each fully sulfated polysaccharide was passed through a Dowex 50W-X8 column to exchange sodium salt to pyridinium salt. Next, each polysaccharide was reacted in dry pyridine with $\mathrm{N}, \mathrm{O}$-bis(trimethylsilyl)acetamide (BTSA) under $\mathrm{N}_{2}$ gas to give a clear solution. Reaction conditions including time and temperature require optimization for the regioselective desulfonation of each polysaccharide. Finally, water was added to decompose excess reagent and silyl esters of sugar hydroxyl groups, the mixture is dialyzed against distilled water, the $\mathrm{pH}$ is adjusted to 7.0, and the resulting 6-O-desulfonated fully sulfated polysaccharide sodium salt is lyophilized.

\section{F. Biological Activities of Chemically Sulfonated Polysaccha- rides}

In recent years, a broad series of polysaccharides has emerged as an important class of bioactive natural products. Sulfated polysaccharides are widespread in nature, occurring in a great variety of organisms. In marine algae, the carrageenans and fucoidans are composed mainly of sulfated galactose and fucose, respectively $(3,13,49)$. Vertebrate tissues express abundant sulfated glycosaminoglycans (50). Invertebrate species are also a rich source of sulfated polysaccharides with novel structures (51-55). We have isolated and characterized the structure of a new sulfated b-galactan from clams (52). In contrast with the algal polysaccharides, invertebrate galactan has simple structure, composed of a single repeating unit (52). The specific pattern of sulfation and the position of the glycosidic linkage vary among different species $(53,54,56)$. It was surprising that these sulfated polysaccharides have been shown the different effects in treating a broad range of diseases, such as immune disorders
告されている。例えば 2,6 ジスルホ $\alpha$ ガラクトメトキシド (46)、 あるいは硫酸化多糖 $(47 、 48)$ のピリジン塩をピリジン中で BTSA、BSTFA あるいは MTSTFA により処理する方法が報告さ れている。この反応はソルボリシスではなく、また他のシリル 化試薬、例えば $N, O-($ ビストリメチルシリル）カルバネート、 TSIM、ヨードトリメチルシランなどでは同様な条件で脱硫酸化 は起こらない。ピリジン中 BTSA を用いた脱 6 硫酸化反応は低 分子化も起こらず、完全硫酸化多糖の選択的脱硫酸化に便利で ある。今回、この方法を用いて先に完全硫酸化した多糖類の脱 6 硫酸化に用いた。

\section{E-3. 脱 6-O-硫酸化完全硫酸化多糖の調製}

完全に硫酸化したアミロース、セルロース、カードランお よびガラクタンはピリジン中 BTSA を用いて脱 6 硫酸化した。 方法の詳細は次の通りである。まず完全に硫酸化した多糖類の ナトリウム塩を水に溶かし、ナトリウム塩をピリジン塩に変換

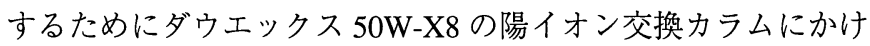
る。次に粉末にした各完全硫酸化多糖ピリジン塩をBTSAを含 む乾燥ピリジン中に懸濁し、窒素ガス置換後透明になるまで反 応を続ける。選択的な脱硫酸化体を得るための反応条件は、 個々の硫酸化多糖により反応時間温度など慎重に最適化しなけ ればならない。最終的に過剩の試薬および糖水酸基シリルエス テルを分解するために水を加え、水に対して透析し $\mathrm{pH} 7.0$ とし た後、凍結乾燥することによって目的の多糖を得る。

\section{F. 化学的硫酸化多糖の生物活性}

近年、多様な多糖類が生理活性を有する重要な天然物の一 つとして注目されている。天然には硫酸化多糖類は広く分布し ており、様々な生物に見出されている。海洋藻類については硫 酸化ガラクトース、フコースを主な成分とするカラゲナン、フ コイダンが知られている(3、13、49)。脊椎動物の組織はグリコサ ミノグリカンに富んでいることはよく知られているが(50)、一 方、無脊椎動物もまた新しい構造を持った硫酸化多糖の宝庫と いってよい(51-55)。私たちも二枚貝から新しい硫酸化 $\beta$-ガラク タンを単離・同定している(52)。藻類の多糖類に比へて、無脊椎 動物由来ガラクタンは構造が単純で、その糖鎖配列も複雑でな い(52)。普通硫酸化のパターン、グリコシド結合の位置などは異

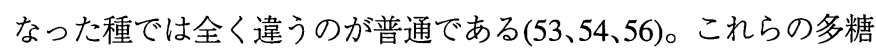
を用いて様々種類の病気、例えば免疫不全、腫瘍に対する作 


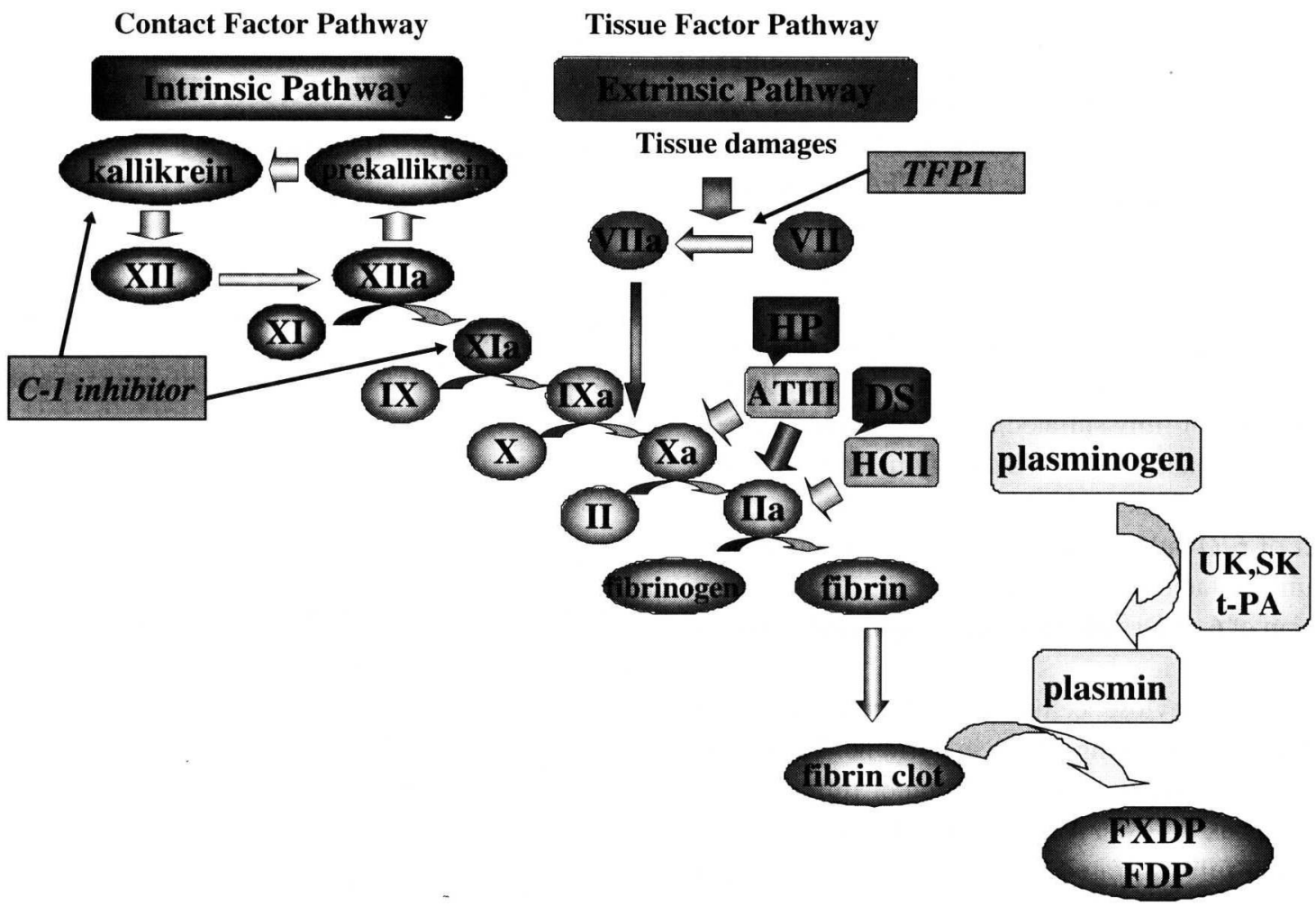

Fig. 2. Schematic representation of the major pathways of the haemostatic cascade. The coagulation factors are designated with Roman numerals and the suffix a indicates a proteolytically activated factor. The intrinsic cascade is initiated when contact is made between blood and exposed endothelial cell surfaces. The extrinsic pathway is initiated upon vascular injury which leads to exposure of tissue factor (TF) (also identified as factor III), a subendothelial cell-surface glycoprotein that binds phospholipid. The two pathways converge at the activation of factor X to Xa. Factor Xa has a role in the further activation of factor VII to VIIa. Active factor Xa hydrolyzes and activates prothrombin to thrombin. Thrombin can then activates factor XI, VIII and V furthering the cascade. Ultimately the role of thrombin is to conver fibrinogen to fibrin and to activate Factor XIII to XIIIa. Factor XIII cross-links fibrin polymers solidifying the clot. After formation of the clot, the fibrinolysis, a normal haemostatic response, is achieved. The major enzyme for fibrinolytic pathway is plasmin, derived from plasminogen, which is activated to plasmin by the tissue type plasminogen activator (tPA) or urokinase-type plasminogen activator (uPA, UK). Finally, plasmin digests the fibrin clot to soluble fibrin degradation product (FDP). Other abbreviations: DS, dermatan sulfate; HP, heparin; SK, streptokinase; TFPI, tissue factor pathway inhibitor.

and tumors, and their activity as anti-inflammatory, anti-ulcer, cholesterol-lowering, blood-glucose-lowering, antiviral agents or antithrombotic agents. An essential prerequisite, when distinct physiological properties are to be attributed to a biological molecule, is knowledge of the structural parameters of such polymers. Initial efforts focused on sulfated homologous polysaccharides by studying their effects on anticoagulant activity, and hyaluronidase inhibition.

\section{F-1. Anticoagulant Activity of Chemically Persulfonated Polysaccharides}

The coagulation and fibrinolytic cascades (Figure 2) comprise a series of zymogens to enzyme conversions, which terminate in the proteolytic enzymes, thrombin and plasmin, respectively. These enzymes catalyze the deposition and removal of
用、あるいは抗炎症作用、抗潰瘍性、コレステロール低下作 用、血糖值低下、抗ウイルスまたは抗凝固活性などを調べてみ ると、その異なった効果に驚かされる。またこれら明確な生理 的性質、あるいは差異がこういった生物分子それ自身にあると すると、多糖類の構造パラメーターに関する知識は必要不可欠 である。最初は単純多糖の硫酸化体の抗凝固活性とヒアルロニ ダーゼ活性に焦点を当て調べた。

\section{F-1. 化学的完全硫酸化体の抗凝固活性}

凝固系および線溶系カスケード (図 2) は一連の酵素前駆体 の酵素への変換過程であり、最終的にトロンビンとプラスミン に帰結する。これらの酵素は生体内でフィブリンの沈着、溶解 
fibrin in vivo. A proper balance between the activities of the two cascades is required both to protect the organism from excessive blood loss upon injury and to maintain blood fluidity within the vascular system. Imbalances are characterized by either bleeding or thrombosis tendencies, the latter of which are manifested as heart attack and strokes.

Deep vein thrombosis (DVT) and closely associated pulmonary embolism (PE) (now accepted as being the expression of a single disease process, namely venous thrombosis) are significant causes of morbidity and mortality in the elderly (57, 58 ). The high incidence of deep vein thrombosis and pulmonary embolism during post-operative and post-traumatic management of patients has prompted investigators to carefully examine the etiology and prevention of the process. Blood coagulation has long been considered pivotal in the development of venous thrombosis. It is known that a hypercoagulable state contributes significantly to the thrombogenic process $(59,60)$.

Most thromboembolic processes require anticoagulant therapy, and the sulfated polysaccharide heparin has been used to reduce thrombosis in post-operative or post-traumatic patients for more than 50 years (61-64). Its potent anticoagulant action is achieved mainly through potentiation of antithrombin and to a lesser degree through heparin cofactor II (HC II). Antithrombin is the major plasma protein inhibiting coagulation enzymes, in particular thrombin and factor Xa (Figure 3). Recently, lowmolecular weight heparin preparations, obtained by fractionation of standard heparin, have become alternatives for prophylaxis of venous thromboembolism. Owing to their long half-life in plasma, high bioavailability and low variability in coagulation
反応を触媒する。二つのカスケードのバランスは、傷害時生体 からの血液の損失を防ぐとともに血管内の血液の円滑な循環に 必須である。これらのバランスが崩れたとき、出血傾向、およ び心臓発作あるいは梗塞を生じることとなる。

年をとるとともに DVTやPE (現在では静脈性血栓症と呼 ばれる同一の疾病と表現されている) は深刻な罹病および死因の 原因の一つとなっている $(57,58)$ 。手術後あるいは外傷を負った 患者の予後に見られるDVT およびPEの高い発症率は、研究者 の高い関心を集め、その病因の解明、および予防法の開発につ ながった。血液凝固は長い間血栓症発現の要因とみなされてい た。血液凝固が起こりやすい状態は血栓症の発現に重要な関わ りを持つことはよく知られている $(59,60)$ 。

ほとんどの血栓塞栓症は抗凝固剤投与による治療が必要 で、硫酸化多糖の一つであるへパリンは、術後あるいは外傷を 負った患者の血栓症を減少させる目的で 50 年以上も使用され ている(61-64)。その強力な抗凝固作用は、一部 HC II を介すも のの、主にアンチトロンビンの薬理効果を増強することによ る。アンチトロンビンは凝固系酵素、特にトロンビンと Xa 因 子の活性阻害作用をもつ主要な血漿タンパク質である (図 3 )。 最近、天然へパリンの分子量分画によって調製した低分子量へ パリンが血栓塞栓症の予防の選択肢の一つになった。長い血槳

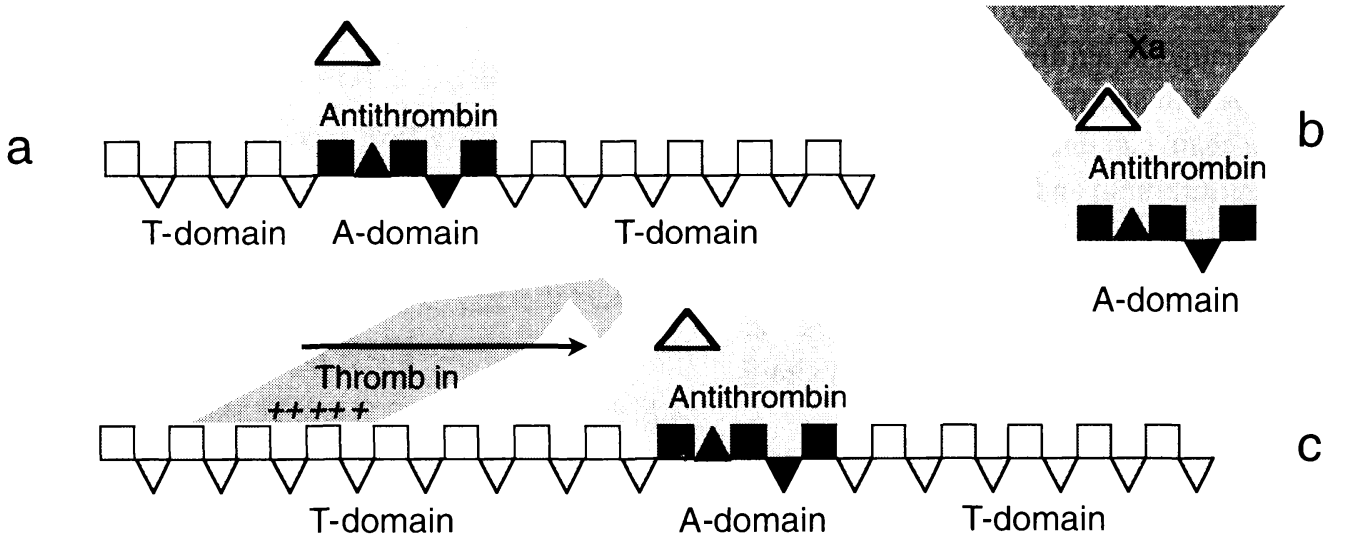

Fig. 3. Inhibition of factor Xa and thrombin by antithrombin and heparin. Heparin is shown here as a repetition of squares (glucosamine units) and triangles (uronic acid units) the non-reducing end of the chain is on the left and the reducing end of the chain is on the right. (a) By binding to the antithrombin pentasaccharide-binding-site (A-domain, black squares and triangles), antithrombin undergoes a conformational change (hatched triangle) in a manner sufficient to inhibit factor Xa without any contribution from the rest of the saccharide chain. This is why the pentasaccharide representing the antithrombin-binding site can inhibit factor Xa (b). In contrast, thrombin inhibition requires attraction by the negative charges of thrombin-binding domain (T-domain). Thrombin slides along the heparin chain until it hooks itself on the exposed loop of activated antithrombin. Because the heparin-antithrombin complex has a well-defined structure, thrombin must approach from the nonreducing side (possibly c) to be irreversibly inhibited. 
(a)

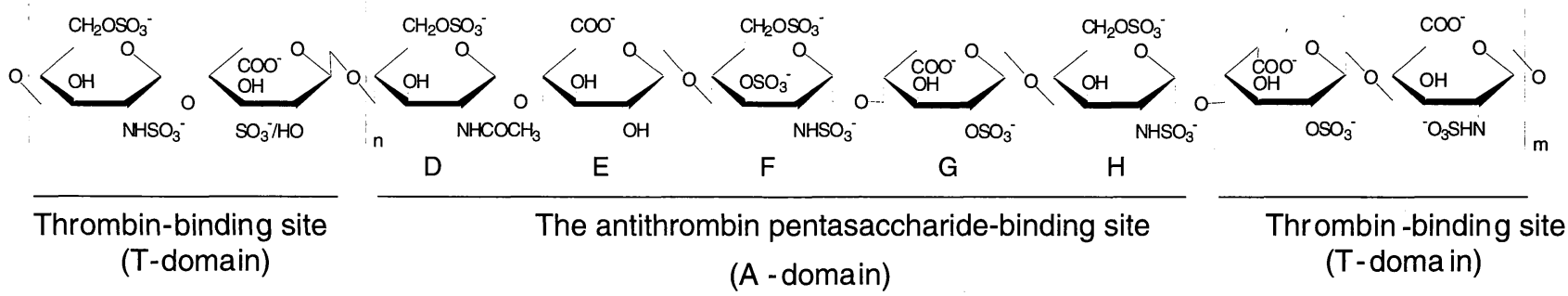

(b)

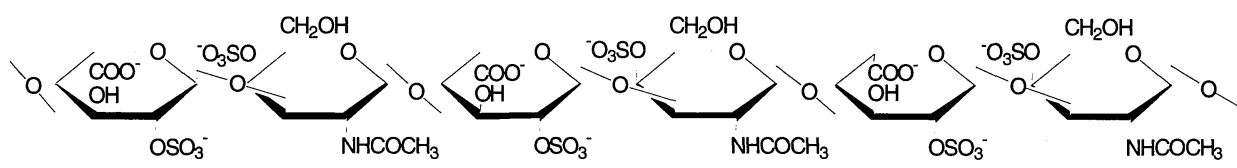

Fig. 4. The antithrombin-binding region in heparin (a) and the heparin cofactor II-binding region in dermatan sulfate (b).

response, low-molecular weight heparins can be administered subcutaneously at fixed dose without the need for laboratory monitoring $(65,66)$. The interaction with antithrombin requires only a short pentasaccharide segment (Figure 3a and 4a), which can be isolated from natural heparins or obtained by chemical synthesis (67). The pentasaccharide, Org31540/SR90107A, the first compound in a new class of synthetic antithrombotic agents, is a highly selective, antithrombin-dependent, indirect inhibitor of activated factor $\mathrm{X}$ (factor $\mathrm{Xa}$ ). It has the potential to improve significantly the risk-benefit ratio for the prevention of venous thromboembolism, as compared with low-molecular-weight heparin (63). Binding of the pentasaccharide to antithrombin causes a conformational change in antithrombin that accelerates its interaction with thrombin and factor Xa by about 1,000 times. The pentasaccharide chain can inhibit the action of factor Xa simply by binding to antithrombin and causing a conformational change (Figure 3b). In contrast, to inactivate thrombin, heparin must bind to both antithrombin and thrombin (Figure $3 c)$, thereby forming a ternary complex (68). This complex can be formed only by pentasaccharide-containing heparin chain composed of at least 18 saccharide units.

Heparin requires antithrombin as cofactor to inhibit thrombin. In congenital or acquired antithrombin deficiencies, the effects of heparin are reduced. Moreover, heparin infusion has been reported to result in a reduction in antithrombin activity, which may promote thrombosis. In such cases, supplementary administration of antithrombin becomes necessary. In addition, a few patients $(-2-7 \%)$ develop thrombocytopenia caused by heparin-reactive immunoglobulins, which induce platelet release and aggregation (69). The hemorrhagic side effect of heparin (including of its low-molecular-weight heparins and
滞在時間、高い利用効率、また低い凝固応答に対する高選択性 によって低分子へパリンはモニターすることなく決まった投与 量で皮下投与することができる(65、66)。アンチトロンビンとの 相互作用には短い 5 糖配列 (図3a, 4a) のみが必要であり、天然 ヘパリンからも単離されているし、また化学合成されている (67)。初の新しいタイプの合成抗血栓薬 5 糖、Org31540/ SR90107A、は高い選択性を持つアンチトロンビン依存性の Xa 因子の間接的阻害薬である。これは低分子へパリンに比べて血 栓塞栓症の予防薬としては高い可能性を秘めている(63)。アンチ トロンビンに対するこの 5 糖の結合はアンチトロンビンの立体 構造変化を誘発し、これがトロンビンあるいは Xa 因子との結 合を約 1000 倍程度加速する。この 5 糖鎖のアンチトロンビン と結合することにより Xa 因子の活性を阻害でき、立体構造変 化を起こす (図 3b)。これに対して、トロンビンの不活化に対し てはヘパリンはアンチトロンビン、トロンビンの両方に結合し (図 3c)、それによって三元複合体を形成している(68)。この複合 体形成には 5 糖構造を含む最低 18 糖構造が必要である。

ヘパリンはトロンビンを阻害するためにアンチトロンビン を必要とする。先天性あるいは後天性のアンチトロンビン欠損 症では、ヘパリンの効果は低下する。さらにへパリンの連続投 与はアンチトロンビン活性の低下を招き、さらには血栓症の促 進をきたすことが予告されている。このような場合、アンチト ロンビンの補給が必要である。更に、患者の中には (2 7\%)へ パリンに対して応答するイムノグロブリンを生じ、これが血小 板の凝集を生み、結果として血小板減少症を発症する(69)。へパ リン (低分子へパリンおよび先の 5 糖を含めて)の副作用として 
pentasaccharide) is another limitation for the use of this compound in some clinical conditions. Moreover, a wide variety of medical conditions required antithrombotic agents with distinctive and unique anticoagulant properties.

Dermatan sulfate, a glycosaminoglycan that is structurally similar to heparin, is currently clinically used in a mixture with heparan sulfate and chondroitin sulfate as an alternative to heparin. It acts primarily on thrombin through HC II not through antithrombin (68). Because of this selectivity, dermatan sulfate has only a weak anticoagulant effect and negligible hemorrhagic complications. HCII inactivates thrombin by formation of a stable 1:1 complex, but does not react with factor $\mathrm{Xa}$. The hexasaccharide shown in Figure $4 \mathrm{~b}$ is the smallest HCII-binding high-affinity oligosaccharide found in dermatan sulfate. Because of its high molecular weight, dermatan sulfate is not well absorbed when administered subcutaneously.

Overall, these observations indicate that alternatives to heparin, perhaps new polysaccharides with fewer side effects and which would be more appropriate for each clinical condition are still required. The investigation for new natural sulfated polysaccharides with potent anticoagulant and antithrombotic action prepared from non-mammalian sources is an attractive alternative.

Sulfated polysaccharides are widespread in nature, occurring in a great variety of organisms. These intact and chemically modified sulfated polysaccharides have been investigated anticoagulant properties for clinical use. In contrast with heparin and dermatan sulfate, the structural features of these chemically sulfated polysaccharides required for anticoagulant activity have not been well characterized. The anticoagulant properties of a range of sulfated polysaccharides that differ in terms of monosaccharide composition and linkage, position of sulfo groups, and anomeric configuration were examined. Since the major inhibitors of serine proteases, such as thrombin (factor IIa) and factor $\mathrm{Xa}$, involved in blood coagulation are antithrom-
知られる出血傾向は、症状によってはこれらへパリンの使用を 制限している。さらに，多種多様の抗凝固剤の出現が様々な医 療のために必要とされている。

デルマタン硫酸もへパリンに類似のグリコサミノグリカン であるが、最近へパラン硫酸、コンドロイチン硫酸との混合製 凨としてヘパリンの代わりに使用されている。デルマタン硫酸 はアンチトロンビンではなく主に HC II を介してトロンビンに 働く(68)。この特異性によってデルマタン硫酸は弱い抗凝固作用 を示し、出血傾向などの厄介な副作用は無視できる。HC II はト ロンビンを安定な $1: 1$ の複合体を形成することでトロンビンを 不活化するが、Xa 因子には働かない。図 $4 \mathrm{~b}$ に示した 6 糖構造 がデルマタン硫酸に見出される、最小で高い結合能をもつ配列 である。デルマタン硫酸は分子量が大きいために皮下投与して もあまり吸収されない。

これらの研究成果は、ヘパリンの代用品として個々の臨床 症状に添った、副作用のほとんどない新しい夕イプの多糖が未 だ要求されているといえる。潜在的に抗凝固活性、抗血栓活性 をもつ新しい非動物性の天然多糖類に関する研究は、魅力的で あるといえる。

硫酸化多糖類は自然界に広く分布し、数多くの生物に見ら れる。天然の、あるいは化学的に修飾した硫酸化多糖類は抗凝 固薬として用いるために調査されてきた。ヘパリンやデルマタ ン硫酸と比べて、これら硫酸化多糖類の抗凝固活性発現におけ る構造的な同定は済んでいない。そこで、調製した硫酸化糖の 単糖組成、グリコシド結合、硫酸基の位置、およびアノメリッ ク配座を調べた。トロンビン (IIa 因子) や Xa 因子のような主 要なセリンプロテアーゼのインヒビターはアンチトロンビンと

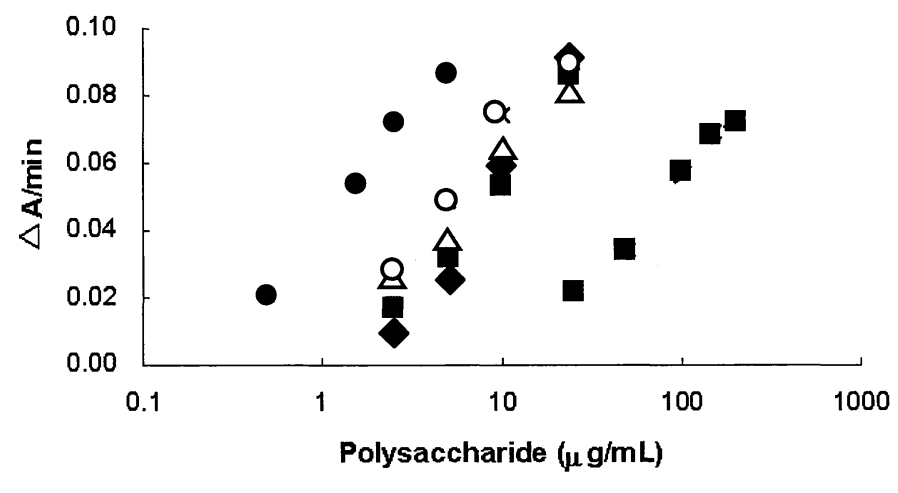

Xylan amylose $\Delta$ Cellulose OCurdlan $\square$ Galactan $\bigcirc$ Heparin

Fig. 5. Amidolytic activity of fully sulfated polysaccharides. Heparin (Sigma, $172 \mathrm{U} / \mathrm{mg}$ ) was used as a comparable standard. 
bin and HCII, the effect of sulfated polysaccharides on the inactivation of thrombin (factor IIa) by human plasma (containing both HCII and antithrombin) and purified antithrombin were investigated to evaluate the anticoagulant activity in this study.

F-2. Effect of $1 \rightarrow 3$ and $1 \rightarrow 4$ Linkages of Chemically Sulfonated Polysaccharides on Their Anticoagulant Activity

We prepared and characterized the chemically fully sulfonated and specifically 6-O- desulfonated $1 \rightarrow 3$, or $1 \rightarrow 4$ linked linear polysaccharides including xylan, amylose, cellulose, curdlan, which are commercially available, and sulfonated Dgalactan isolated from clams. Next, their anticoagulant activity was examined using an amidolytic assay. Heparin (172 units/ $\mathrm{mg}$ ) was used as a reference substance to estimate the relative anticoagulant action of these sulfated polymers. The effect, of fully sulfated polysaccharides and fully sulfated polysaccharides that had been 6-O-desulfonated, on inactivation of chromogenic amidolytic activity of thrombin was examined using human plasma and is illustrated in Figure 5. Concentration-dependent inhibition of liberated chromogen was seen with both sulfated polysaccharides and with heparin. Because plasma contains both antithrombin and $\mathrm{HCII}$ it was necessary to examine activity in plasma-free systems containing purified antithrombin to understand the mechanism of action. These studies showed that all of the sulfated polysaccharides failed to inhibit thrombin activity both in the absence of plasma even in the presence of the purified antithrombin (data not shown). These results conclusively demonstrated that the sulfated polysaccharides show no direct or antithrombin mediated thrombin inhibition, but instead accelerated thrombin inhibition through HCII.

The antithrombin activity, of fully sulfated polysaccharides and fully sulfated polysaccharides that had been 6-Odesulfonated, observed in human plasma is summarized in Figure 6 and compared to standard heparin $(172 \mathrm{U} / \mathrm{mg})$. It is ap-
HC II なので、これら硫酸化多糖類のトロンビンの不活化に対す る影響は、アンチトロンビンと HC II を含むヒト血槳、および 精製したアンチトロンビンを用いて調べた。

\section{F-2. 1 $\rightarrow 3 、 1 \rightarrow 4$ 結合の違いによる抗凝固系への効果}

直鎖のキシラン、アミロース、セルロース、カードラン、 および二枚貝から単離した硫酸化ガラクタンの完全硫酸化体、 およびこれらの脱 6 硫酸化体を用いて調べた。まずはじめに抗 凝固活性としてアミド結合分解活性を調ベた。ヘパリン (172 単 位 $/ \mathrm{mg}$ ) 対照に用い、各硫酸化多糖類の比活性を求めた。完全 硫酸化体とその脱 6 硫酸化体の効果はトロンビンのアミド結合 分解活性に対して、ヒト血漿を用いて測定した結果を図 5 に示 す。測定系において分解されて遊離してくる色素の量には、へ パリンおよび硫酸化多糖類の濃度依存的阻害効果が見られた。 血漿はアンチトロンビンと HC II の両酵素を含んでいるので、 血漿を含まない純粋なアンチトロンビンのみを用いた系での検 討を行い、阻害メカニズムを調べたところ、すべての化学的に 調製した硫酸化多糖類は、血漿が存在しないと、またアンチト ロンビンが存在しても阻害活性を示さなかった(デー夕は示して いない)。これらの結果から、調製した硫酸化多糖類の凝固阻害 活性は、直接、あるいはアンチトロンビンを介してではなく、 HC II を介するものと結論付けられた。

完全硫酸化体、およびこれらの脱 6 硫酸化体のヒト血漿 を用いた場合のアンチトロンビン活性は、標準品として用いた ヘパリンの活性 (172 単位 $/ \mathrm{mg}$ ) とともに図 6 に要約されている。

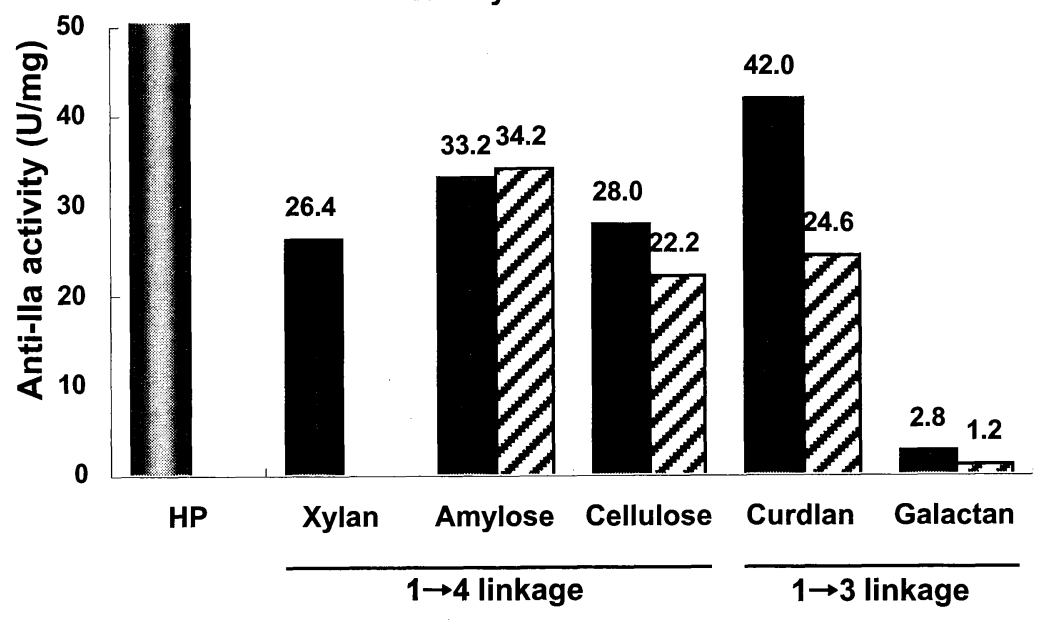

Fig. 6. Anti-IIa Activity of fully sulfated polysaccharides. The activity is expressed as the international U/mg. 
parent that while each of the fully sulfated $1 \rightarrow 4$ or $1 \rightarrow 3$ linked polysaccharides exhibited plasma-mediated antithrombin activity, this activity is -4-fold lower than that of heparin. The fully sulfated galactan showed the lowest anti-IIa activity among the samples tested, presumably be attributed to its lower molecular weight. Unexpectedly, in the fully sulfated polysaccharide that have been 6-O-desulfonated, $1 \rightarrow 3$ linked polysaccharides such as curdlan and galactan lost $50 \%$ of their anti-factor IIa activity compared to those of their fully sulfated counterparts. In contrast, the activity of the $6-O$-desulfonated $1 \rightarrow 4$ linked polysaccharides, such as amylose and cellulose, were unchanged compared to their fully sulfated counterparts. These data strongly suggest that the presence of two adjacent sulfo groups at C-2 and $\mathrm{C}-3$ positions are required to inhibit factor IIa activity and the contribution of 6-O-sulfo group might be significant in $1 \rightarrow 3$ linked polysaccharides for the activity.

\section{F-3. Effect of Chemically Sulfated Polysaccharides on Hy- aluronidase Inhibition}

Hyaluronidases (HAases, EC 3.2.1.35) are enzymes known to be involved in inflammatory reactions and metastasis of tumor cells. These enzymes usually exist in an inactive form that is activated by metal ions and other agents (70). Hyaluronidase is also a component of the venom of a wide variety of organisms, including bees, wasps, hornets, spiders, scorpions, snakes and lizards. In the human body, hyaluronidase is found both in organs (testes, spleen, skin, eye, liver, kidney, uterus and placenta) and body fluids (tear liquid, blood and sperma) (71). The hyaluronidases are a group of neglected enzymes that have recently shown to have greater significance, due to the increasing attention being given to their substrate, hyaluronan (hyaluronic acid, HA). These enzymes are a class of $\beta 1-4$ endoglucosaminidases. A key role of this enzyme has been recognized in a number of basic biological processes, such as embryogenesis $(72)$, carcinogenesis $(73,74)$, wound healing $(75)$, angiogenesis (76), and inflammation (77). The activity of hy-
この結果から明らかなように、1 $\rightarrow 3$ 、あるいは $1 \rightarrow 4$ 結合したそ れぞれの完全硫酸化多糖は血漿タンパク質を介した抗凝固活性 を示す一方、その活性はへパリンの 4 分の 1 程度でしかない。 完全硫酸化したガラクタンにいたっては調べた多糖類の中で最 も抗 IIa 活性が低く、おそらくその分子量の低さが影響してい るのだろうと推定された。予期しなかったことであるが、1 $1 \rightarrow 3$ 結合したカードランとガラクタンの場合、脱 6 硫酸化体はもと の完全硫酸化体の約 $50 \%$ の抗 IIa 活性を失ってしまった。それ に対して、1 $\rightarrow 4$ 結合したアミロースやセルロースの脱 6 硫酸化 体はほとんどもとの完全硫酸化体と同様の活性を示した。これ らの結果は C-2, C-3 に結合した隣接する硫酸基の存在と、 $1 \rightarrow 3$ 結合多糖においては 6 位の硫酸基の寄与が大きいことを強く示 唆している。

\section{F-3. 化学的に硫酸化した多糖類のヒアルロニダーゼ阻害活性}

ヒアルロニダーゼ類 (以下 HAase、EC3.2.1.35) は炎症反応 および腫瘍の転移に関与する酵素として知られている。これら の酵素は通常不活性型で存在し、金属イオンあるいは他の物質 によって活性化される(70)。ヒアルロニダーゼはまた幅広く多様 な生物、例えば蜜蜂、ジガバチ、スズメバチ、蜘蛛、さそり、 蛇、トカゲなどのの毒液に含まれる。ヒトの体内では、ヒアル ロニダーゼは臓器 (精巣、脾、皮膚、眼球、肝、腎、子宮、胎 盤) と体液 (涙、血液、精漿) の両方に見出される(71)。ヒアルロ ニダーゼ類はこれまで見過ごされてきた酵素の一群で、最近は その基質であるヒアルロン酸に対する関心が高まるにつれて注 目されるようになった、 $\beta 1 \rightarrow 4$ エンドグルコサミニダーゼであ る。この酵素は、多くの生物学的な基本過程、例えば肧形成 (72)、発ガン(73、74)、創傷治癒(75)、血管新生(76)、炎症(77)な どに関与する鍵となる酵素であると認識されるようになった。 ヒアルロニダーゼの活性は様々な活性化物質 (前立腺、脾、腎、

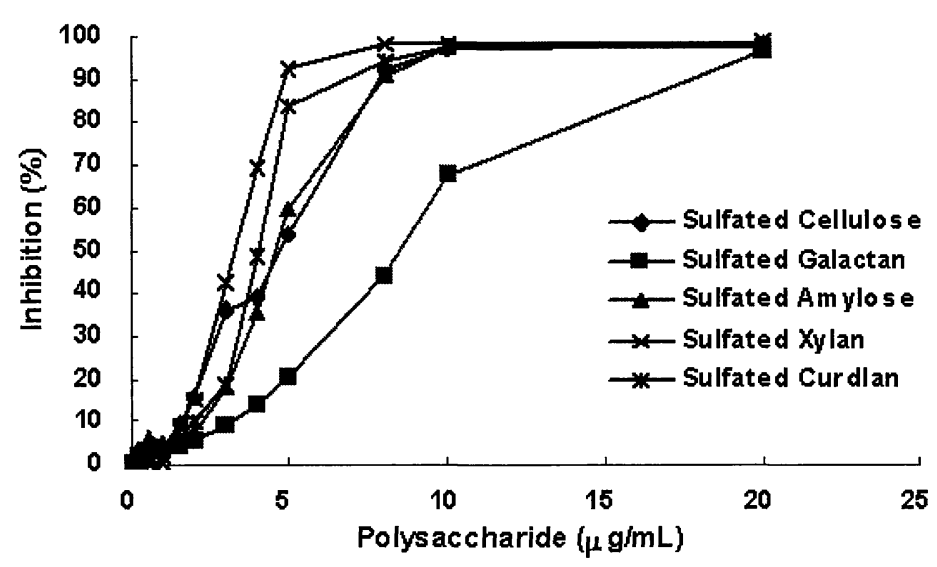

Fig. 7. Inhibition of hyaluronidase activity of fully sulfated polysaccharides. 


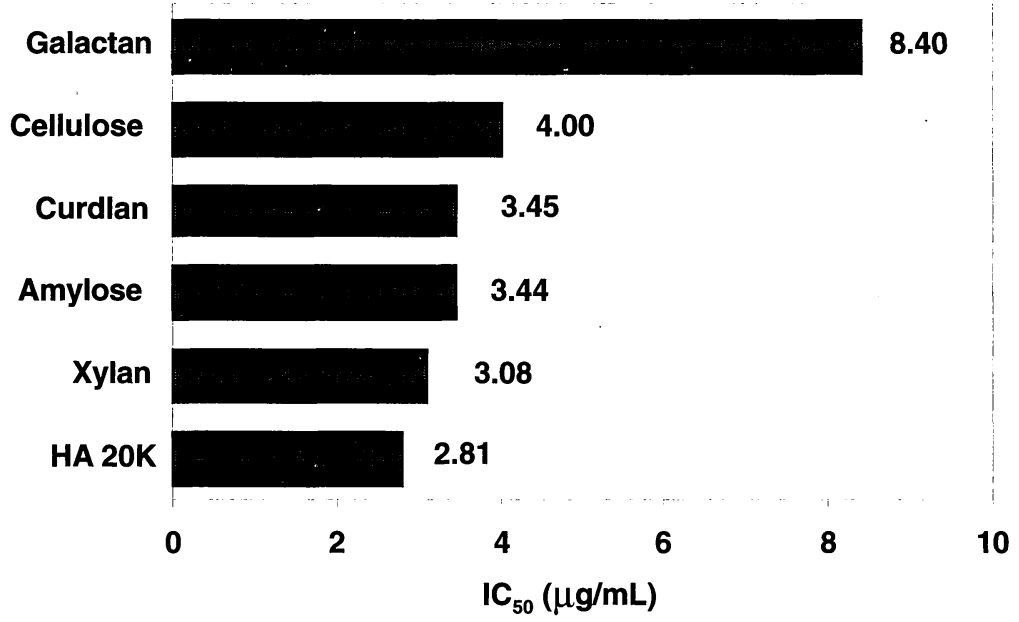

Fig. 8. $\mathrm{IC}_{50}$ of fully sulfated polysaccharides on hyaluronidase activity.

aluronidase is modulated by various activators (adrenalin, histamine and acid phosphatases formed in the prostate, spleen, kidney, erythrocytes and platelets) and inhibitors (antihistamine, salicylate, heparin, dicumarene, vitamin C and flavonoids) (78). Among the glycosaminoglycans, only heparin shows hyaluronidase inhibitor. Chemically $O$-sulfonated glycosaminoglycans showed $\mathrm{IC}_{50}$ values of hyaluronidase inhibition that correlated with the degree of $O$-sulfonation. Heparin was found to inhibit hyaluronidase activity in a noncompetitive fashion, while sulfonated HA strongly inhibited hyaluronidase through both competitive and noncompetitive effects (79).

Until recently, the most commonly used HAase assays were based on the measurement of the generation of new reducing $\mathrm{N}$-acetylglucosamido groups, or a decrease in viscosity, turbidity, and microtiter-based assays (80). Such assays are often either insensitive, lack specificity, and are complicated, requiring skillful assay techniques.

The HAase inhibitory activity of the persulfonated polysaccharides was determined using a flow injection assay (FIA) (79). All experiments were performed in duplicate. As shown in Figure 7, each of the fully sulfated polysaccharides inhibited HAase in a concentration-dependent fashion. The 50\% inhibitory concentration $\left(\mathrm{IC}_{50}\right)$ of fully sulfated polysaccharides on HAase (Figure 8) was $3.08 \mathrm{mg} / \mathrm{mL}$ (sulfated xylan), 3.44 $\mathrm{mg} / \mathrm{mL}$ (sulfated amylose), $3.45 \mathrm{mg} / \mathrm{mL}$ (sulfated curdlan), 4.0 $\mathrm{mg} / \mathrm{mL}$ (sulfated cellulose), and $8.4 \mathrm{mg} / \mathrm{mL}$ (sulfated galactan). All of fully sulfated polysaccharides showed less inhibition than sulfated hyaluronan $(2.81 \mathrm{mg} / \mathrm{mL})$. The sulfated amylose, cellulose, curdlan, and xylan exhibited the HAase activity inhibition at the same level, whereas the inhibitory effect of sulfated galactan was approximately 2-fold less than that of the others.

\section{G. Structure, SAR and Conclusions}

Sulfated polysaccharides have been found in a variety of
赤血球、血小板で産生されるアドレナリン、ヒスタミン、酸性 ホスファターゼ) や阻害物質 (抗ヒスタミン、サリチル酸、ヘパ リン、ジクマレン、ビタミンC、フラボノイド)によって調節さ れる(78)。グリコサミノグリカンの中では唯一ヘパリンが阻害活 性を示す。化学的 $O$-硫酸化グリコサミノグリカンのヒアルロニ ダーゼに対する $\mathrm{IC}_{50}$ は、硫酸化度に依存していた。ヘパリンの ヒアルロニダーゼ阻害は非競合的であることが見出され、一方 硫酸化したヒアルロン酸は競合的、非競合的の両者による阻害 であることが明らかになっている(79)。

つい最近まで、最も沉用されていたヒアルロニダーゼ活性 測定法は、生成する $N$-アセチル基の還元末端を測定するか、あ るいはヒアルロン酸水溶液の示す粘度、濁度の測定あるいはマ イクロタイターアッセイ (80)であった。これらの測定法はしば しば感度、特異性のどちらかに欠け、複雑で熟練を要する方法 である。

今回ヒアルロニダーゼ活性の測定法は私たちが開発した FIA によった(79)。すべての測定は 2 回ずつ行い、図 7 に示すように 個々の硫酸化した多糖は濃度依存的にヒアルロニダーゼを阻害し た。個々の硫酸化多糖のヒアルロニダーゼに対する $\mathrm{IC}_{50}$ はそれ ぞれ $3.08 \mu \mathrm{g} / \mathrm{mL}$ (硫酸化キシラン)、3.44 $\mu \mathrm{g} / \mathrm{mL}$ (硫酸化アミロー ス)、 $3.45 \mu \mathrm{g} / \mathrm{mL}$ (硫酸化カードラン)、 $4.0 \mu \mathrm{g} / \mathrm{mL}$ (硫酸化セルロー ス)、 $8.4 \mu \mathrm{g} / \mathrm{mL}$ (硫酸化ガラクタン) であった (図 8 )。すべての 調べた硫酸化多糖は硫酸化ヒアルロン酸に比べて $(2.81 \mu \mathrm{g} / \mathrm{mL})$ 低 い阻害活性であった。硫酸化アミロース、セルロース、カード ラン、キシランはほとんど同じレベルのヒアルロニダーゼ阻害 活性を示したのに対し、硫酸化ガラクタンはこれらの約 2 分の 1 の阻害活性しか示さなかった。

\section{G. 構造、SAR および結論}

硫酸化多糖類のは多くの海洋動物、植物微生物に広く見出 
marine animals, plants and microorganisms. Lentinan [a branched $\beta(1 \rightarrow 3)$-glucan] sulfate, curdlan $[\beta(1 \rightarrow 3)$-glucan] sulfate and chemically sulfonated galactan $[\beta(1 \rightarrow 3)$-galactan $]$ from marine clam species Meretrix petechialis showing potent anti-HIV activity, but very low anticoagulant activity. The mechanism of action of sulfated polysaccharides on various biological activities are believed to be dependent on their polysaccharide backbones as well as the molecular weight, the degree and position of sulfo groups on sugar residues, and interestingly on the glycosidic linkages present in these polysaccharides. The correlation between biological activity and structure of polysaccharides having simple core structure and high homogeneity is leading to a better understanding of the relationship between structure and biological activity. Cellulose, amylose, curdlan, and galactan are useful for such studies as they are all naturally abundant and simple $\beta(1 \rightarrow 4), \alpha(1 \rightarrow 4), \beta(1 \rightarrow 3)$-glucans and $\beta(1 \rightarrow 3)$ galactan. After being chemically fully sulfonated using pyridinesulfur trioxide in dimethylformamide their structure is determined. ${ }^{1} \mathrm{H}$ NMR spectroscopy, IR spectroscopy and chemical compositional analysis is used to show that chemical sulfonation is complete. Fine structural details including conformational flipping of core sugar residues caused by negative charges on sulfo groups, can often also be observed. NMR spectroscopy at $30^{\circ} \mathrm{C}$ demonstrates an altered conformation of monosaccharide residues from ${ }^{4} C_{1}$ to ${ }^{l} C_{4}$ in the persulfonated polysaccharide derivatives. The molecular weight of these fully sulfated polysaccharides can be estimated between 8,000 and 39,000 based on gel permeation chromatography with conductivity detection or by gradient PAGE. Fully sulfated $1 \rightarrow 4$ and $1 \rightarrow 3$ linked polysaccharides show expected enhanced anti-factor IIa activity in comparison with the activity displayed by heparin (172 units/mg) standard. A conformational change in the monosaccharide residues is responsible for this substantial increase in anti-factor IIa activity. It is also interesting that desulfonation at a specific position, C-6, causes a loss of the activity on only $1 \rightarrow 3$ linked fully sulfated polysaccharides, without affecting on the activity of $1 \rightarrow 4$ linked fully sulfated polysaccharides. Consequently, a pair of neighboring sulfo groups such as at C-2/C-3 or C-4/C-6 might be required for this anticoagulant activity. These $1 \rightarrow 4$ linked fully sulfated polysaccharides that had been 6-Odesulfonated might be useful in eliminating nonspecific binding to proteins preventing side-effects associated with clinical anticoagulants, such as thrombocytopenia. The molecular weight of these sulfated polysaccharides might also play a role in the anticoagulant activity of fully sulfated polysaccharides.

In conclusion, the sulfonation of polysaccharides can result in increased specific and non-specific binding to a wide range of biologically important proteins. Polysaccharide chain sequence and sulfo group substituents and conformational stereostructure all play a significant role in the observed bioactivity of sulfated polysaccharides.
されている。レンチナン (枝分かれ $\beta 1 \rightarrow 3$ ガラクタン) 硫酸、 カードラン $(\beta 1 \rightarrow 3$ ガラクタン) 硫酸および化学的に硫酸化した 二枚貝由来ガラクタンは抗 HIV 活性を示したが、非常に低い抗 凝固活性をもつ。様々な生物活性における硫酸化多糖類の作用 メカニズムは、多糖類の糖鎖骨格、分子量、硫酸基の位置だけ でなく、興味深いのはグリコシド結合にも依存すると信じられ ている。単純なコア構造と高い均一性を持つ多糖類の構造と活 性相関は、構造と活性との間の関係を理解する上で重要であ る。セルロース、アミロース、カードラン、そしてガラクタン はこれらが天然に豊富に存在すること、単純な $\beta 1 \rightarrow 4 、 \alpha 1 \rightarrow 4$ グ ルカン、 $\beta 1 \rightarrow 3$ ガラクタンであることから、今回のような研究 に役に立つ。DMSO 中で三酸化イオウーピリジン錯体を用いた化 学的硫酸化後、これらの構造は同定された。プロトンNMR、赤 外、化学分析を用いて分析したところ調製した硫酸化多糖は完 全に硫酸化されていた。硫酸基の陰電荷による反発が原因で起 こる本来の糖残基のコンホメーションの反転が明膫に確認され た。 $30^{\circ} \mathrm{Cで}$ 測定した完全硫酸化多糖の NMR デー夕は、それを 構成する単糖のコンホメーションが ${ }^{4} C_{1}$ から ${ }^{I} C_{4}$ に変化してい ることを示していた。またこれらの完全硫酸化多糖類の分子量 は、PAGE および電気伝導度検出器を装着したゲルろ過 HPLC で調べたところ 8000 から 34000 と推定できた。完全硫酸化し た $1 \rightarrow 4$ 結合および $1 \rightarrow 3$ 結合した多糖は、ヘパリン標準品 (172 単位 $/ \mathrm{mg})$ と一緒に調べたところ、期待通り抗 IIa 活性を増強し た。単糖残基のコンホメーション变化がこの抗 IIa 活性の実質 的な増加に寄与していた。また、完全硫酸化体から 6 位硫酸基 を除くと $1 \rightarrow 3$ 結合した多糖の場合のみ活性を失い、1 $1 \rightarrow 4$ 結合 した多糖では影響がなかった。従って隣接する C-2/C-3 P C-4/ C-6 などの硫酸基が凝固活性に必要であるに違いない。これら $1 \rightarrow 4$ 結合した多糖の完全硫酸化脱 6 硫酸化体は血小板減少症な どの副作用の原因となる非特異的なタンパク質との結合を避け られる意味で有用であるに違いない。これら硫酸化多糖類の分 子量もまた完全硫酸化多糖類の示す抗凝固活性に役割を演じて いるはずである。

結論として、多糖類の硫酸化は特異的・非特異的な様々な タンパク質への結合を引き起こすことができ、糖鎖配列、硫酸 基の数や位置、立体構造などの全てが硫酸化多糖に観察される 生物活性に重要な役割を演じている。 
Trends in Glycoscience and Glycotechnology Vol.15 No.81 (January 2003) pp.29-46

\section{References}

1. Hooper, L.V., Manzella S. M., and Baenziger J. U. (1996) FASEB J. 10, 1137-1146

2. Linhardt R. J., and Toida T. (1997) In Carbohydrate in Drug Designing, (J. W. Zbigniew, A. N. Karl, eds.), Marcel Dekker, Inc., New York, pp. 277-341

3. Witvrouw M. and De Clerq E. (1997) Gen. Pharmc. 29, 497-511

4. Stringer S. E. and Gallagher J. T. (1997) Int. J. Biochem. Cell. Biol. 29, 709-714

5. Lindahl U., Backstrom G. Thunberg L. (1983) J. Biol. Chem. 258, 9826-9830

6. Villanueva G. B. (1984) J. Biol. Chem. 259, 2531-2536

7. Gunay N. S., Linhardt, R. J. (1999) Planta Med. 65, 301-306

8. Linhardt, R. J., Hileman R. E. (1995) Gen. Pharmac. 26, 443-451

9. Greiling H., Scott J. (eds.)(1989) Keratan sulfate chemistry, biology, chemical pathology, T. J. Press Ltd., Great Britain

10. Suzuki A., Toyoda H., Toida T., Imanari T. (2001) Glycobiology 11, 57-64

11. Swarte V. V., Joziasse D. H., Mebius R. D., van den Eijnden E., Kraal G. (1998) Cell Adhes. Commun. 6, 311-322

12. Linnemann G., Reinhart K., Parade U., Philipp A., Pfister W., Straube E., Karzai W. (2000) Intensive Care Med. 26, 1540-1546

13. Millet J., Jouault, S. C., Mauray S., Theveniaux J., Sternberg, C., Boisson V. C., Fischer A. M. (1999) Thromb. Haemost. 81, 391-395

14. Carlucci M. J., Pujol C. A., Ciancia, M., Noseda, M.D., Matulewicz M. C., Damonte E. B., Cerezo A. S. (1997) Int. J. Biol. Macromol. 20, 97-105

15. Tobacman J. K., Wallace R. B., Zimmerman M. B. (2001) Med. Hypotheses. 56, 589-598

16. Hirano S. (1996) Biotechnol. Annu. Rev. 2, 237-258

17. van der Lubben I. M., Verhoef J. C., Borchard G., Junginger H. E. (2001) Eur. J. Pharm. Sci. 14, 201-207

18. Muzzarelli R. A., Tanfani F., Emanuelli M., Pace D. P., Chiurazzi E., Piani M. (1984) Carbohydr. Res. 126, 225-231

19. GhoshP. (1999) Semin. Arthritis. Rheum. 28, 211-267

20. Flexner C., Barditch-Crovo P. A., Kornhauser D. M., Farzadegan H., Nerhood L. J., Chaisson R. E., Bell K. M., Lorentsen M. J., Hendrix C. W., Petty B. G. (1991) Antimicrob. Agents Chemother. 35, 2544-2550

21. Miao H. Q., Ishai-Michaeli R., Peretz T., Vlodavsky I. (1995) J. Cell Physiol. 164, 482-490

22. Yoshida T. (2001) Prog. Polym. Sci. 26, 379-441

23. Edwards G., Breckenridge A. M. (1988) Clin. Pharmacokinet. 15, 67-93 .

24. Firsching-Hauck A., Nickel P., Yahya C., Wandt C., Kulik R., Simon N., Zink M., Nehls V., Allolio B. (2000) Anticancer Drugs 11, 69-77

25. Garg H. G., Joseph P. A., Thompson B. T., Hales C. A., Toida Imanari T., T., Capila I., Linhardt, R. J. (1999) Arch. Biochem. Biophys. 371, 228-233

26. Logeart D, Prigent-Richard S., Jozefonvicz J., Letourneur D. (1997) Eur. J. Cell Biol. 74, 376-384

27. Haroun-Bouhedja F., Ellouali M., Sinquin C., Boisson-Vidal C. (2000) Thromb. Res. 100, 453-459

28. Brown G. D., Gordon S. (2001) Nature 413, 36-37

29. Blondin C., Fischer E., Boisson-Vidal C., Kazatchkine M. D., Jozefonvicz J. (1994) Mol. Immunol. 31, 247-253

30. Paper D. H., Vogl H., Franz G., Hoffman R. (1995) Macromol. Symp. 99, 219-225

31. Kasbauer C. W., Paper D. H., Franz G. (2001) Carbohydr. Res. 330, 427-430

32. Zhang L., Zhang M., Zhou Q., Chen J., Zeng F. (2000) Biosci. Biotechnol. Biochem. 64, 2172-2178

33. Mishima T., Murata J., Toyoshima M., Fujii H., Nakajima M., Hayashi T., Kato T., Saiki I. (1998) Clin. Exp. Metastasis 16, 541-550

34. Fernandez L. E., Valiente O. G., Mainardi V., Bello J. L., Velez H., Rosado A. (1989) Carbohydr. Res. 190, 77-83

35. Beeson J. G., Chai W., Rogerson S. J., Lawson A. M., Brown G. V. (1998) Infect. Immun. 66, 3397-3402

36. Schaeffer D. J., Krylov V. S. (2000) Ecotoxicol. Environ. Saf. 45, 208-227

37. De Clercq E. (2000) Med. Res. Rev. 20, 323-349

38. Takano R., Yoshikawa S., Ueda T., Hayashi K., Hirase S., Hara S. (1996) J. Carbohydr. Chem. 15, 449-457

39. Maaroufi R.M., Tapon-Bretaudiere, J., Mardiguian J., Sternberg C., Dautzenberg M. D., Fischer A. M. (1990) Thromb. Res. 59, 749-758

40. Nagasawa K., Uchiyama H., Wajima N. (1986) Carbohydr. Res. 158, 183-190

41. Toida T., Maruyama T., Ogiata Y., Suzuki A., Toyoda H., Imanari T., Linhardt, R. J. (1999) Int. J. Biol. Macromol. 26, $233-241$

42. Toida T., A. Suzuki, K. Nakajima, A. Chaidedgumjorn, and Imanari T. (2000) Glycoconj. J. 17, 393-399

43. Kantor T. G., Schubert M. (1957) J. Am. Chem. Soc. 79, 152-153

44. Inoue Y.,, Nagasawa K. (1976) Carbohydr. Res. 46, 87-95

45. Nagasawa K., Inoue Y., Kamata T. (1977) Carbohydr. Res. 58, 47-55

46. Takano R., Matsuo M, Kamei-Hayashi K., Hara S., Hirase S. (1992) Biosci. Biotechnol. Biochem. 56, 1577-1580

47. Matsuo M., Takano R., Kaemi-Hayashi K., Hara S. (1993) Carbohydr. Res. 241, 209-215

48. Takano R., Ye Z. Z., Ta T. V., Hayashi K., Kariya Y., Hara S. (1998) Carbohydr. Lett. 3, 71-77

49. Nishino T., Aizu Y., Nagumo T. (1991) Agric. Biol. Chem. 55, 791-796

50. Mathews M. B. (1975) In “Connective tissue: macromolecular structure and evolution.” Berlin: Splinger-Verlag, pp. 93-206

51. Santos J. A., Mulloy B., Mourao P. A. (1992) Eur. J. Biochem. 204, 669-677

52. Kim Y. S., Jo Y. Y., Chang I. M., Toida T., Park Y., Linhardt, R. J. (1996) J. Biol. Chem. 271, 11750-11755

53. Amornrut C., Toida T., Imanari T., Woo E. R., Park H., Linhardt, R. J., Wu S. J., Kim Y. S. (1999) Carbohydr. Res. 321, 121-127

54. Alves A. P., Mulloys B., Diniz J. A., Mourao P. A. (1997) J. Biol. Chem. 272, 6965-6971

55. Pereira M. S., Mulloys M., Mourao P. A. (1999) J. Biol. Chem. 274, 7656-7667

56. Farias W. R., Valente V, Pereira M. S., Mourao P. A. (2000) J. Biol. Chem. 275, 29299-29307

57. Anderson F. A., Wheele H. B. (1992) J. Vasc. Surg. 16, 707-714

58. Goldhaber S. Z., Morpurgo M. (1992) JAMA. 268, 1727-1733

59. Herbert J. M., Bernat A., Maffrand J. P. (1992) Blood 80, 2281-2286

60. Rosenberg R. D., Aird W. D. (1999) N. Engl. J. Med. 340, 1555-1564

61. Leyvraz P. F., Richard J, Bachmann F. (1983) N. Engl. J. Med. 309, 954-958 
62. Collins R., Scrimgeour A., Yusuf S., Peto R. (1988) N. Engl. J. Med. 318, 1162-1173

63. Turpie A. G., Gallus A. S., Hoek J. A. (2001) N. Engl. J. Med. 344, 619-625

64. Crafoord C., Jorpes E. (1941) JAMA. 116, 2831

65. Hull R. D., Pineo G. F. (1993) Haemostasis 23 Suppl 1, 2-9

66. Weitz J. I. (1997) N. Engl. J. Med. 337, 688-698

67. Lindahl U., Backstrom G., Thunberg L. (1983) J. Biol. Chem. 258, 9826-9830

68. Bourin M. C., Lindahl U. (1993) Biochem. J. 289, 313-330

69. Warkentin T. E., Levine M. N., Hirsh J. (1995) N. Engl. J. Med. 332, 1330-1335

70. Sawabe Y., Nakagomi K., Iwakami S., Suzuki S., Nakazawa H. (1992) Biochim. Biophys. Acta. 1137, 274-278

71. Menzel E. J., Farr C. (1998) Cancer Lett. 131, 3-11

72. Meyer M. F. Kreil G. (1996) Proc. Natl. Acad. Sci. USA. 93, 4543-4547

73. Knudson W. (1996) Am. J. Physiol. 148, 1721-1726

74. Sherman L., Sleeman J., Herrlich P., Ponta H. (1994) Curr. Opin. Cell Biol. 6, 726-733

75. Esters J. M., Adzick N. S., Harrison M. R., Longaker M. T., Stern R. (1993) J. Pediatr. Surg. 28, 1227-1231

76. West D. C., Kumer S. (1989) Ciba. Found. Symp. 13, 187-201

77. Edelstam G. A., Laurent U. B., Lundkvist O. E., Fraser J. R., Laurent T. C. (1992) Inflammation 16, 459-469

78. Li M. W., Yudin A., Vande Voort C. A., Sabeur K., Primakoff P., Overstreet J. W. (1997) Biol. Reprod. 56, 1383-1389

79. Toida T., Ogita Y., Suzuki A., Toyoda H., Imanari T. (1999) Arch. Biochem. Biophys. 370, 176-82

80. Frost G. I., Csoka T. B., Wong T., Stern R. (1997) Biochem. Biophys. Res. Commun. 236, 10-15

Received on February 2, 2003, accepted on March 31, 2003

\section{Profile of the Authors}

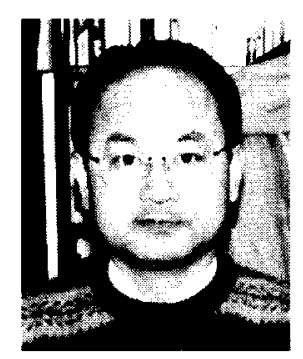

Toshihiko Toida graduated in Analytical Chemistry in 1978 at Chiba University, Faculty of Pharmaceutical Sciences, and obtained his Ph.D. in Analytical Chemistry in 1983 at the same University. From 1983 to 1989, he was Research Associate/Lecturer in the Department of Biochemistry in Teikyo University, College of Medicine directed by Professor Ineo Ishizuka, and he was focusing on the structure and function of acidic glycosphingolipids. From 1989 to 2003, he was Associate Professor in Chiba University, Faculty of Pharmaceutical Sciences, directed by Professor Toshio Imanari. He has spent a sabbatical year at Professor Robert Linhardt's laboratory in the University of Iowa. College of Pharmacy in 1996. Currently, he was promoted to Professor at Chiba University. His main research interests are focusing on the structures and physiological functions of sulfated polysaccharides from the natural products such using NMR, MS and SPR etc.
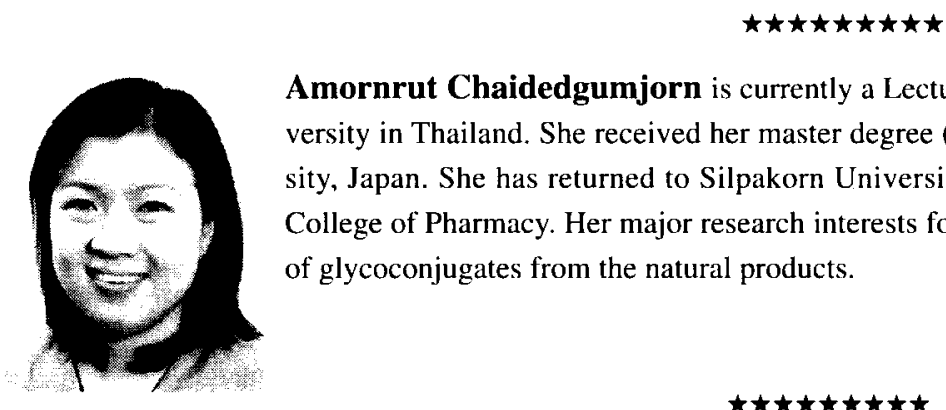

Amornrut Chaidedgumjorn is currently a Lecture in College of Pharmacy at Silpakorn University in Thailand. She received her master degree (1999) and Ph.D. (2002) from Chiba University, Japan. She has returned to Silpakorn University and is a Lecture in Silpakorn University, College of Pharmacy. Her major research interests focus on the structure and biological functions of glycoconjugates from the natural products.

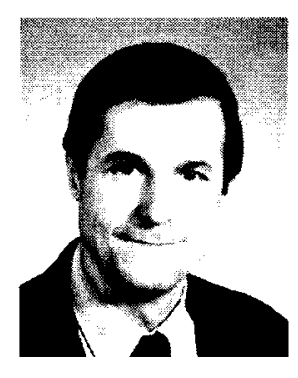

Robert J. Linhardt received his B. S. degree in chemistry from Marquette University (1975) and his Ph.D. degree from Johns Hopkins University in organic chemistry (1979). His interest in heparin lyases began during his postdoctoral studies at Massachusetts Institute of Technology. It was there, while working with Professor Robert Langer on a bioreactor to remove heparin from the blood, that he first purified the heparin lyase enzymes. He continued this work on heparin, becoming a faculty member at the University of Iowa in 1982, with a focus on heparin structure and heparin's biological activities mediated through its interaction with proteins.

Dr. Linhardt is currently the F. Wendell Miller Distinguished Professor of Chemistry, Medicinal 
Chemistry and Chemical and Biochemical Engineering at the University of Iowa. Dr. Linhardt will be joining the faculty at Rensselaer Polytechnic Institute as the Constellation Chair of Biocatalysis and Metabolic Engineering this summer.

Dr Linhardt has published over 300 research papers and holds 35 patents. He is the regional editor of Current Organic Synthesis and Mini Reviews in Organic Chemistry and is on the editorial boards of Analytical Biochemistry and Applied Biochemistry and Biotechnology and the Journal of Carbohydrate Chemistry. He has been honored with the Horace S. Isbell award from the Carbohydrate Division of the American Chemical Society, the AACP Volwiler Research Achievement Award for Pharmaceutical Research sponsored by Abbott Pharmaceuticals and the Claude S. Hudson Award from the American Chemical Society. 